\title{
THE FACTORS AFFECTING CAREER GUIDANCE AND CURRENT STATUS OF CAREER GUIDANCE SERVICES IN TURKEY
}

\author{
Emel Ültanır \\ Hasan Kalyoncu University, Turkey \\ E-mail: emultanir@yahoo.de
}

\begin{abstract}
The purpose of the present study is to investigate the factors affecting career guidance and their reflections of the career guidance services given in the country. Based on a literature review, it is known that career guidance services can be a part of economic and social development. In the present study, these factors are analyzed under these headings as the structure of the region, economic conditions (labor force of the country and employment), historical and socio-cultural factors (family structure, changing values) and educational factors. Moreover, it is emphasized that the country is the only secular country and only candidate for the European Union membership among the Muslim communities. After drawing a framework with these factors, the state of the country in guidance services and its reflections abroad were investigated. It is of great importance to draw the attention to such issues in Turkey and to develop "career guidance programs" as in developed countries.
\end{abstract}

Key words: career guidance, influential factors, career guidance services and reflections abroad.

\section{Introduction}

In the United States of America, the history of career guidance started in 1909 with the opening of Career Office by Frank Parson in Boston and he is regarded as the father of the field of career guidance. Then, within the following 50 years, in the field of career guidance, career selections were done based on the scores of the tests designed for recruitment purposes (Herring, 1998). Super (1951) redefined career guidance and established developmental career model in the occupational literature. Career models were started be called as developmental career guidance within the framework of vocational guidance. In the late 1960s, the term career guidance was widely adopted instead of the term vocational guidance (Herr and Cramer, 1996). Career guidance as a classical stereotype is generally believed to be a kind of service belonging to class counseling. Very often, in a class, quantitative and qualitative evaluative information and processes are used.

Career guidance and career counseling are both old and new terms (Herr and Cramer, 1996). They also stated (1996) that it has a history of 75 years, that is, it has a history of 90 years up to now. The concept of career guidance is a more comprehensive term because it dates back to early periods of vocational guidance and includes life span career development of an individual. Though both terms are old, they gained their current meanings in 1970s.

In America and large part of the world, the importance of career guidance and counseling is expressed as follows (Herr \& Cramer, 1996): Maturation of theoretical perspectives, dramatic changes brought about by national and global economies in occupational structures, increase in the rates of unemployment among adolescents and adults, increase in the number of literate people and development of calculation and flexibility skills among the labor force of industrialized nations, improving living standards, improving efficiency among the work force and resulting 
PROBLEMS

OF EDUCATION

IN THE $21^{\text {st }}$ CENTURY

Volume 48,2012

136

changes in the composition of labor force, changes in processes and career development services indicate the importance of career counseling. Traditionally, career guidance is given at schools and by public employment agencies. Schools provides such guidance to students who are on the point of selecting a profession or going on studying at higher levels; public employment agencies; on the other hand, help the unemployed looking for a job (OECD, 2004).

According to Sultana (2009) career guidance is not merely seen as a viable policy response to the usual set of challenges which, if successfully addressed, lead to a number of public and private goods - such as a better balance between the supply and demand of skills and social inclusion. Rather, career guidance is seen to vehicle a total world view which celebrates individual volition and the centrality of work, which gives self-determination and self-fulfilment pride of place, and which encourages the labour market to be organised according to a specific rationality and logic (p.5).

In a meeting held in Lisbon in 2000, the strategic mission to be realized by European Union was summarized to be "speeding the process of transition from industrial economy to information-based economy and to information society, structural reform encouraging competition and innovation, modernization of European social model, overcoming the challenges faced by people in making investment and social integration, healthy economic view and sustaining the hopes for positive growth and application of proper macroeconomic policy".

Lisbon agenda, identifies career guidance as one of four key actions to create open, attractive and accessible learning environments. It calls for strengthening the role, quality and coordination of career guidance services to support learning at all ages and in a range of settings, empowering citizens to manage their learning and work (p.5).

Guidance promotes employability and adaptability by assisting people to make career decisions both on entering the labour market and on moving within it. Guidance also helps improve the effectiveness and efficiency of education and training provision and labour market instruments, by promoting a closer match to individual and labour market needs and by reducing non-completion rates (Sultana, 2004).

In 1950s, the term "Counseling" was introduced to Turkey by the experts brought from the United States of America such as Rufi, Tomkins, Beals and Mills through the seminars they gave to students concerning their abilities, interests and needs. With the start of planned growth period in $60 \mathrm{~s}$, the idea that "for positions in the society to be given the individuals having the necessary qualifications, occupational orientations should be organized at schools" was incorporated into the First Five-year Growth Plan (Özgüven, 1990). Then, in 1962, supporting decision was made stating "importance should be attached to carrying out educational activities suitable for the characteristics of students" (Council of Ministry of National Education, 1962).

Guidance is also attractive to policy-makers because it can help address a whole range of labour market issues, it can improve labour market outcomes and efficiency, and it can support economic development goals. Policy-makers are therefore increasingly looking to guidance for support in addressing labour market shortages, tackling mismatches between labour supply and demand, reducing the effects of labour market destabilisation, dealing with unemployment, and improving labour mobility (Sultana, 2009 p.8).

Savickas (2000) stated that as a result of rapid change in social order, the nature of the business world has changed. The workers must face the complex demands of variety existing in global economy, continuously changing technologies and vastly challenging and competitive job markets. The obligation for individuals to manage their own careers, new structuring and disappearance of work places having hierarchic functioning have great influences on the career counseling adopting the mentality of "business as usual" (Guindon \& Richmond, 2005). In this respect, economic and technological advancements in society shape the career guidance 
services. According to Watts and Fretwell (2004), less developed countries, particularly the ones having labor force more than needed (that is, there are some people unemployed) may prefer to attach greater importance to the development of career guidance services than the developed countries. Factors such as global competition, information technologies, structure of telecommunication systems in countries and compatibility between education and job markets may affect career guidance services.

Career guidance services can be a part of economic and social development. The present study analyzed various articles, reports and reviews written about career counseling. Among these, special attention was paid to the Organization for Economic Cooperation and Development (OECD, 2004), the European Commission Report (Sultana, 2004) the World Bank (Watts \& Fretwell, 2004), (Sultana \& Watts, 2008) and (Akkök \& Watts, 2003).

The purpose of the present study is to investigate the career guidance and counseling services in Turkey with their international reflections and make possible projections for the future based on the current state of some factors (structure of the region and economic, historical, socio-cultural and educational) within the context of globalization and rapid changes taking place in the World in the 21 st century.

\section{The Nature of the Region}

Turkey is characterised a number of economic, historical, socio-cultural and educational factors which seem likely to have constrained the development of career guidance services. These factors have influenced the forms which existing services have taken. Many also represent factors that need to be taken into account in any future development of these services, to ensure that they are embedded in their context and not merely imported from elsewhere. (Sultana \& Watts, 2008, p. 22).

Turkey has a unique geographic location that bridges Europe and Asia, and controlling the major waterway between the Black Sea and the Aegean and Mediterranean Seas. It is neighboured with in Europa (Greece and Bulgaria), in Asia (Armenia, Georgia) and in the Middle East (Iran, Iraq and Syria). Being a developing country, Turkey is subject to the usual problems of industrialization and urbanization, including a significant increase in the breakdown of family networks, and the modification of traditional cultural patterns (McWhirter, 1983).

Until the early 20th century, the Ottoman Empire continued its existence. The majority of the population of Turkey is Muslim and it is a secular state with its own specificities. That is the only Mediterranean country which is a candidate for membership in the European Union. This means that it has been more subject to direct EU policy influence (Sultana \& Watts, 2008; p. 21-22). Mustafa Kemal Atatürk was the pioneer of secularism in Turkey. Many modernization attempts such as adoption of Latin alphabet instead of Arabic Alphabet, adoption of Western calendar, replacement of Islamic law by Swiss law by adapting it to secular legal system, giving the right of electing and being elected to women and adoption of western way of dressing up were made under the leadership of Atatürk (Yerin-Güneri, 2011).

\section{Economic Factors. Labor Force and Employment in Turkey}

As of 1980, globalization and social changes taking place in the world have resulted in changing values and attitudes of individuals in Turkey. In countries where the number of young people (15 years old) is high, it is of great importance to continue economic growth and to create new job opportunities. Fast increase seen in the number of young people at working age leads to increase in the number of "dependent people" who should be cared about by working people in the whole population and the rate of working population remains relatively low. This means ineffective use of resources in the country. According to Turkish Labor Force Report 
PROBLEMS

OF EDUCATION

IN THE $21^{\text {st }}$ CENTURY

Volume 48,2012

138

issued by the World Bank in 2006, the number of the people participating in the workforce was 20 million in 2000 (Gür, 2008).

Though the number of people employed in agricultural sector decreased, it is still quite high when compared to European Union countries. There are significant differences between western and eastern regions of the country as well as between urban and rural areas. While there are more developed regions in the western part of the country, there are less developed regions in the eastern part and among these regions; there are remarkable differences in terms of education and job opportunities. The reasons for the discrimination against female children in eastern regions are economic hardships, parents' low level of education, cultural factors and crowded families where priority is given to male children rather than female children when it comes to education. Turkey has an unemployment insurance for eligible citizens who end up without a job. Yet, newly created jobs in Turkey are characterized by their requiring unqualified workforce for little money in small or medium scale organizations or in unregistered sector. Women's ratio of participation in labor force is low in urban areas; yet, very high in rural unregistered family economies. Those working off the workers do not have social security.

Another factor adversely affecting the problem of employment is the demographic dynamic of our country. As every year, almost 750.000 new workers need to be added to workforce, the rate of economic growth may not be big enough to meet this need. When the age composition of the employed is examined, it is seen that there is a decline in 15-19 and $50+$ age groups; that is, the performance of economic growth has not been able to digest this change. When compared to the same period of previous year, the total population of the county increased by 1.218 .000 and reached 73.482 .000 and the population at the working age increased by 1.160 .000 and reached 54.599 .000 . The ratio of participation in the workforce was $50.5 \%$ in May, 2012. Of the total workforce, 15.9\% are those in the age group of 15-24 (TÜIK, 2012).

According to the household employment statistics issued by TUIK for the period of June, 2012, non-institutional population in Turkey increased by 1.218.000 when compared to the same period of previous year. The number of young people aged 15-24 is 54.122.000 and when the education and age distributions of the workforce are examined, it is seen that $16.4 \%$ of the total workforce is made up of young people in the age group of 15-24. The workforce participation ratio of the people having education level lower than high school education was estimated to be $69.3 \%$ among the males and $26.8 \%$ among the females. The workforce participation ratio for the university graduate males is $84.8 \%$ and $69.4 \%$ for the university graduate females. When the results of the TÜIKK Household Workforce Research, unemployment compensation applications issued by İŞKUR and short-term employment expectations covering the period of June, 2102 are analyzed, following findings can be reported:

- The increase in workforce participation ratio is still going on among women; yet, it is decreasing among men and young people.

- Strong growth observed in 2011 had positive impacts on employment and led to increase in employment of men and in service sectors.

- Service sectors constitute $84 \%$ of the new employment, small number of people has been recruited in agriculture and construction sectors but there is a weakening increase in the employment in industry.

- Half of the increase in employment came from job finding university graduates, the share of the university graduates in the total increase in employment increased from $31 \%$ to $57 \%$; however, the share of those having education lower than high school dropped from $57 \%$ to $15 \%$. The ratio of unemployment decreased to $10.2 \%$.

One of the tendencies reflecting the change is the movement of workforce from rural areas to urban areas. The net immigration ratio in Northeast Anatolia, Middle East Anatolia, Southeast Anatolia and Central Anatolia where agriculture-centered employment is dominant varies between $26 \%$ and $7.5 \%$. While immigration from rural areas to urban areas makes it 
possible for the economy to be constructed on a more modern ground, it leads to decrease in rural workforce. For instance, when women immigrate to urban areas, they remain out of the workforce as they do not the qualifications required by urban economy. In terms of the employment of men, it can be argued that while they are living in rural areas, they are in the position of hidden unemployed, when they come to cities, they become apparent unemployed or they become the part of the informal sector as a street vendor, lottery seller or simit seller etc. (Karagöl \& Akgeyik, 2010, p. 7-8). As a result of the observations made in one of the cities located in Southern regions, Mersin, it was found that through the projects carried out with the women immigrating from Eastern regions in 2005 and 2006, they learned reading and writing and gained some skills such as tailoring and made some contributions to their family budget.

\section{Historical Factors}

The Turkish history has three main axes. These are traditions brought from Middle Asia to Anatolia, Islamic period and Imperial era (Güngör, 1986, 107). While ancient Turks had a religion based on Shamanism, after they embraced Islam, they transformed from nomadic community level to settled community with classes. Following this, Arabic-Persian civilization became more dominant than Chinese civilization on Turks. As a result of these influences, kinship-based relations were replaced by land-based relations (Kivilcıml1, 1996, p. 63-79). The empire conception of the Ottoman State was transferred from Byzantium Empire and from the moment of its foundation, Ottoman State has been always in contact with Europe. This means that it was a European state. Expansion of the state to Anatolia and Asia was realized after it became stronger in Europe. Yet, it did not have any connections with Antique Rome, Christianity and Feudality; hence, it was always isolated from Europe (Kılıçbay, 2000, 56).

\section{Socio-cultural Factors}

Since Turkish society was introduced to concepts such as modernization, westernization and development by means of The Imperial Edict of Gülhane, its traditions and consumption patterns have undergone some changes and has adopted a new living style based on new norms and values (Kongar, 1995, p. 228). With the same edict, the concept of secularism (having same distance with all the religions) and every citizen's being equal in front of the state became popular. In 1937, with the addition of the article "Turkish Republic does not have an official religion and it is a secular state" to the constitution, and Turkish Republic became the first Muslim secular country on the world (İşçi, M. 2002). Among the 10 principles accepted by Turkish constitution in 1982, one is the principle of secularity (Ültanır, 2012, p.174).

Between 1963 and 1967, according to first five-year growth plan, a 15-year perspective was developed for the field of industry. Together with the phenomenon of immigration from rural areas to urban areas in our country, the period of illegal construction of shabby houses started. The type of family living in such houses tried to acquire new skills, and wanted their children to be educated well as a result, the societal framework of such families changed (Özkalp, 1993, p.115). Since the early 1980's due to developments in telecommunications, Turkey has become more receptive to western ways of life, and the transition from traditional values to western ones has greatly accelerated (Mocan-Aydın, 2000).

In the foundation years of the Republic, some decisions were made to fortify the position of the woman in society. With legal rights stated in civil law passed in 1926, the woman was granted the right of electing and being elected, selecting a profession and applying for positions in the state. Though the urban family type in Turkey is a nucleus family, it has some features different from the modern family in industrialized countries. The individual typically possesses the web of intimate personal relations including family members, relatives and close neighbors. 
PROBLEMS

OF EDUCATION

IN THE $21^{\text {st }}$ CENTURY

Volume 48,2012

140

Such personal relationships and strong family relationships are still common (E.O. Imamoğlu, R.V. Kullar, M. Imamoğlu \& Kuller, 1993). With the introduction of the woman into business life following industrialization, the duties assumed by the family members underwent some changes and some of them were carried out by institutions. The children of a working mother started to be cared about by elderly members of the family or kindergartens and pre-school institutions. Hence, in some areas, the relative groups were replaced by business or educational institutions (İşçi, 2002).

As in each society, the family has an important role in the selection of occupation. Families particularly the ones in urban areas make great investments on their children's education. Ültanır (2005) reports that families from middle and high socio economic classes usually adopt child-centered attitudes towards bringing up their children. That is, whole family life is focused on children's education and wishes. The desire to seek for the opportunities to find a prestigious job, which is one of the most important factors affecting career preferences, has led families to direct their children to these prestigious professional fields. As a result of this trend, Psychological Counseling and Guidance programs at education faculties of universities have become one of the most desired programs.

According to Sultana \& Watts (2008), Western notion of individual career guidance might be seen as inappropriate and /or irrelevant by some groups, since traditional notions of respect toward elders often induce young people to follow pathways decided for them by parents, older siblings, close relatives and relatives in the clan (Sultana \& Watts, 2008, p. 24). This situation may be of great importance for tribal communities in South East and East Anatolia regions and families living in rural areas.

In connection to this, the study carried out by Hofstede (2001) with national and regional cultural groups revealed that there is a considerable resistance affecting both the behaviors of individuals and those of institutions. Hofstede believes that there is a differentiation between individually-oriented cultures and its opponent collectivist cultures. Individuals living in many Mediterranean and Arabic communities usually adopt collectivist orientation; hence, the rarely act independently of any group or institution.

According to Sümer (1998) Turkish culture is fundamentally collectivistic in the sense that the family retains priority, but this collectivism coexists with highly individualistic trends in the systems of education and economy, where market rules necessiate and justify competition (p.126).

\section{Educational Factors}

As of 2102, compulsory education in Turkey has become 12 years. According to new regulations passed, this 12-year period is constructed as four-year elementary education, four-year secondary education and four-year high school education. In this way, vertical and horizontal passages among different levels have become possible. The school starting age has dropped to 5 years old (66 months). At secondary school, that is at secondary level, besides the courses of Turkish Language, Mathematics, Science, Social Studies and Foreign Language, there are some elective courses offered and in this way background required for high school education is provided for students. Enrollment in secondary schools does not require taking any exam and it is automatically performed through e-school system based on the address of the student. In order to select the high school to be attended, $8^{\text {th }}$ graders should take Level Determination Exam (SBS) and some special talent exams and according to the results of these exams, they can attend either general high school, Anatolian high school or Science high school etc. Psychological Counseling and Guidance Services are provided by means of leisure time activities at elementary schools and counseling/social activities courses at secondary schools. At high schools, students are exposed to counseling and guidance course program of secondary 
schools. The main purpose of counseling and guidance is to allow the use of proper resources in career selection. For this purpose, there are some attempts to set up national occupational information system and in this way, it is assumed that students will be able to get to know themselves better and learn about job opportunities, accordingly, they can plan their education better (MEB, Zorunlu Eğitim, 2012).

However, based on the researcher's opinion which made at schools in Turkey, it can be said that there is a shortage of psychological counselors (with the name of guidance teacher in education system) and this leads to lack of counseling services offered. The number of the students in formal education is 16.905.143 in 2011-2012 school year and this means that we need about 19.000 counselors (M.E.B. Statistics, 2012). In some schools having 1000 or more students, there is only one counselor; hence, it is clear that required educational-occupational and social-interpersonal services cannot be provided. The most outstanding manifestation of this lack of occupational counseling is students' opting for professions they know or see around and as a result of this; many people may regret selecting the job they have in later times.

Now, the female children of the families emigrating from rural areas to urban areas want to study at university to have a good job and this shows that there is a change in generally adopted view of genders in Turkey. Expectation of the families immigrating to urban residences for their female children to study and have a job leads to this prejudicial conflict. The expatiation of the parents that when they get older, they are looked after by their female children has been eliminated. After reviewing the historical, socio-cultural and educational facts, general structure of career counseling in Turkey will be discussed.

\section{Career Counseling in Turkey: Current Status}

In Turkey, the psychological counselors working in the field of psychological counseling and guidance PCG work in many different fields such as education, industry, health, rehabilitation etc. PCG teaching is carried out at the education faculties of universities in the form of "schoolbased programs". School counselors offer all personal-social, educational and vocational PCG services. In our education institutions, what is expected most from psychological counselors (guidance expert) is to provide vocational guidance and counseling. Yet, in undergraduate PCG programs offered at universities, there are only two (theoretical and applied) vocational guidance courses. At some universities, similar courses are offered within graduate programs (Ankara, Hacattepe, ODTÜ Universities etc.).

There is no undergraduate career guidance program in Turkey, even not at graduate programs as a sub-field of PCG. But, in recent years, the need to start "career counseling" programs as graduate programs has been highly emphasized in various department of PCG meetings. In our country, there are about 57 counselor education undergraduate programs and 14 graduate programs in 2012. A decision was made by The General Headquarter of Turkish PCG Association to apply to the Higher Commission of Academic Evaluation and Quality Development in Education (YÖDEK) to carry out accreditation works in the field of PCG (Dept. of PCG, Concluding Declaration, 2012). Most of the graduates of PCG programs work as school counselors at schools connected to the Ministry of National Education. In 2003, a graduate program entitled "Human Resources and Career Counseling" was inaugurated within the Faculty of Political Sciences at Ankara University. The target population of the program was determined to be the personnel to be recruited in private employment agencies, human resources departments of firms, and in the fields of personnel and managerial counseling. Moreover, at Istanbul Bahçeşehir University, career counseling services are provided for students to help them determine their vocational tendencies. Within the Bahçeşehir University Lifelong Learning center, there is a Career Development Counseling (Global Career Development FacilitatorGCDF-Turkey) certificate program (Bahçeşehir University, 2012). 
PROBLEMS

OF EDUCATION

IN THE $21^{\text {st }}$ CENTURY

Volume 48, 2012

142
Moreover, within the framework of Organization for Economic Co-operation and Development (OECD), a report was prepared to determine the strengths and weaknesses of vocational counseling services offered in the country with the support of World Bank (2003) and this report emphasizes the following points (Akkök and Watts, 2003): The associates who are effective in the provision of career counseling services are Ministry of National Education (MoNE), Ministry of Labor and Social Security, ISSKUR, Higher Education Council (HEC); Turkish Statistical Institute and some labor unions. While such services are provided by IŞKUR in the form of finding a job, it should take a new form within the framework of the relations with European Union. "Life-long learning" policies adopted by some international organizations such as World Bank, OECD, European Commission and UNESCO are another factor affecting Vocational Guidance Services offered in our country.

American School Counselors Association (ASCA) states that 1 psychological counselor should serve 250 students for effective services to be provided (ASCA, 2005). The number of the students that should be served by 1 psychological counselor in Turkey varies between 905 and 2836 (Akkök \& Watts, 2003). General counseling services given at schools generally focus on Personal and Social Guidance and Educational Counseling and less importance is attached to Career Education and Guidance. Counseling services offered at elementary and secondary schools of the Ministry of National Education are carried out by "classroom guidance teachers" and "school counselors". With the introduction of new education system in 2012, "Counseling and Career Guidance" course became required for $8^{\text {th }}$ graders.

Within the framework of creating an effective information community and economy efforts starting with Lisbon process in European countries, the Higher Education Field works were started to be shaped with Bologna process. Works performed in this field were published in the report "Quality Principles and Standards in Higher Education" in 2005. Quality assurance system in Turkey was designed within the context of "National Competencies Framework" in such a way as to include accreditation and evaluation elements in order to guarantee the quality of learning outcomes determined on the basis of a program. In 2005, "Higher Education Academic Evaluation and Quality Development Guideline" was set up by Higher Education Council. Higher Education Academic Evaluation and Quality Development Council (YÖDEK) was established (YÖK, 2012). At some universities, counselors working as specialists in "Psychological Counseling and Guidance Centers" or "Vocational Planning and Placement" units carry out guidance and counseling services for university students (Akkök, 2006).

For adult women who cannot be involved in education or labor market, Public Education Centers offer some courses such as reading and writing or mastering some skills. In informal education, counseling services are rare; yet, there is an urgent need for them. Ültanır \& Ültanır (2012) revealed that there is not clear job description for these people in these centers yet, and apart from few, there is no such post in these centers. In the reports issued by the $13^{\text {th }}$ National Education Council (1990) concerning "Informal Education" stated that there is a need to support counseling activities to improve informal education institutions, to appoint university graduate counselors to Public Education Centers to provide comprehensive and effective education in these centers, and counseling services should not be limited to courses given in these centers but also they should provide guidance to local public to solve unemployment and other problems. Accurate knowledge of adult students /nontraditional students' issues can enable counselors to effectively advocate for them, making professional services more relavant to their specific needs in personal, vocational and educational area (p.97).

Unemployed adults are the main recipients of career guidance across Europe. Often, the providers are Public Employment Services (PES). Unemployed adults may have access to career information and guidance in other settings than those provided by the PES. Most often, community based organizations provide services to specific groups, especially if they are the target of national equity policies (Sultana, 2004 p. 55-58). 
As can be seen from the above-given information, counseling services provided at universities are limited and career guidance services provided for adults are even more limited. The roles that should be assumed by İşKUR and Counseling and Research centers are not clear and there is a general lack of strategic leadership and coordination in the field.

\section{Future Projections}

In this article, some factors affecting career guidance in Turkey will be presented. Then, the general state of career guidance and counseling services will be discussed. Based on the present state, some suggestions can be made. The field which was initially called as guidance within counseling services was first aroused interest in our country in 1950s and developed under the influence of research and applications in America. In recent years, however, more influence of European Union has been felt due to European Union membership efforts and Bologna process. With the project supports given by European Union, new formations were started in Career Guidance and Counseling services in the country (Akkök and Zelloth, 2010, Yeşilyaprak, 2011). Many European countries are not much ahead of us in terms of educating such counselors. One of the strengths of Turkish career guidance system is that general counseling services offered at schools by professional guidance counselors have a good structure. However, such services are provided in Germany by workers having a strong background and having courses in different fields such as psychology, education, social studies and economy in addition to their own subject area. The number of workers having graduate education in the field of guidance is increasing (Sultana, 2004).

With the 5209 article passed by YÖK on 19.10.2011, the number of PCG programs giving graduate education dropped to 14 . According to this article, there must be certain number of academicians in order to initiate a graduate program in the field of PCG. There is still lack of academicians holding $\mathrm{PhD}$ required by increasing number of PCG programs. Though there are some efforts to start graduate programs for the sub-fields of PDR in the country, there are just two in Ankara and İstanbul.

The need for career counseling is continuously increasing due to increasing number of young people in the country. $15.9 \%$ of the total labor force is made up of young people aged 15-24. These young people should be provided with necessary vocational counseling services to get to know themselves and develop their interest and abilities. Last year, the increase in total gross national product was $\% 8$ but this year it has dropped to $\% 4$ due to economic recession in Europe and internal turmoil seen in some Middle Eastern countries such as Iran, Iraq, and Syria. Increasing total gross production and employment means informing those who want to be recruited about possible vocational fields.

In our country, the students may select their programs to be attended at university by chance. Therefore, it is commonly observed that some students want to change their programs while at university or they do not like their jobs and want to change it after graduation. Such factors negatively affect working efficiency and accordingly the organizations and economy of the country. There are many instances where a graduate of a science program may go on his/her career in social sciences and may feel happier.

The young people who are at the point of selecting a job for themselves need career guidance to know themselves better and to obtain information about the newly emerging professional areas. Some resources such as "Guidebook of Occupations" Kuzgun (1998) should be updated so that they include newly emerging professions. For this purpose, there is a need for career counselors to be employed at schools, IŞKUR and private employment agencies.

Vocational guidance tools and materials are developed by academicians working at universities (Kuzgun, 2000). Information to be given to students at secondary school about professions and business world is insufficient (Akkök, 2003). There is a need for organized works to update such information and present it to young people. 
PROBLEMS

OF EDUCATION

IN THE $21^{\text {st }}$ CENTURY

Volume 48, 2012

144

University entrance exam that should be taken by students who want to go to a university is not to reveal students' capabilities but to assess the achievement. If an individual does not have the qualifications to do a job, he/she may not be a successful member of the profession. Kuzgun (2000) states that while determining his choices, a high school student does not pay much attention to his/her abilities (p.47). For young people to get to know themselves well, they should be provided with career guidance services both at secondary level and high schools.

Moreover, there is a need for career guidance services to be given to adults planning to have an employment through informal education. We have Public Education Centers in almost every town and city providing training services for the adults being out of the formal education system. Teaching programs offered here cover both vocational fields and hobbyrelated activities. Especially in the last 20 years, there has been increasing immigration from Eastern and South Eastern regions to the industrialized areas located in Southern and Western regions. This has resulted in a greater need for such centers.

In Turkey the role of Public Education centers can be summarised as: "To provide; Pre vocational training, career change, a variety of work experience, including further education programs within industry and to apply the vocational technical education programs. Through researching local markets the centres aim to identify key areas of employment and thus provide courses related vocations directed at developing work forces that will be able to integrate into the local climate (Ültanır \& Ültanır, 2010, p.5).

\section{Conclusion}

When the points emphasized in the present article are considered, following evaluations can be made: career guidance is shaped with the effects of historical, economic, socio-cultural dynamics. In this respect, Yeşilyaprak (2011) points out that career guidance and counseling policy objectives should be defined at national level (p. 17). The technology and economy of a society determine the dynamics of its business world, societal welfare of workers, and employment opportunities. Orientation of the workers according to their abilities and qualifications can be made through career guidance services.

In European Union countries, the issues targeted to be achieved by career guidance are "lifelong learning, social inclusion, development of labor market and economy". These objectives should be included within the targets of Turkey involved in the global competition. In this regard, career guidance policies should be constructed parallel to economic, social and technological developments.

Rapid increase seen in the working age population results in relative lowness of the working population. Hence, economic growth cannot digest this change. On the other hand, domestic immigration to urban areas leads to increasing unemployment, difficulties in adaptation, isolation etc., therefore, career guidance services can be conducive to the development of projects to integrate these immigrants to the society.

In relation to guidance education, career guidance and counseling courses given at the undergraduate level should be reorganized. While designing career counseling master program, economic development needs of the country should be considered and sufficient importance should be attached to the issue. According to Fidan (2005) graduate degree for career counseling would be so helpful and some Turkish counselor educators are aware that career counseling master program has to be developed. As a conclusion, in order to be able to develop career guidance services in Turkey, the economy of the country, its education and business world should be in harmony in such a way as to support social developments. 


\section{References}

Akkök, F., \& Watts, A. G. (2003). Public Policies and Career Development: A Framework for the Design of Career Information, Guidance and Counselling Services in Developing and Transition Countries. Country Report on Turkey. World Bank. March.

Akkök, F. (2006). Vocational knowledge, guidance and counseling services, Turkey country report. Ankara: İŞKUR Documents.

Akkök, F., \& Zelloth, H. (2010). Lifelong guidance-a feasible policy option for Turkey. $\quad$ Ankara: İŞKUR Dökümanları.

Büyüktanır, D., Duke, C., Karasar, N., Tileylioğlu \& Toth, J. S. (2006). Driving force for the success of Turkey: Life-long Learning Policy Document. MEGEP: SVET Project of Strengthening Vocational Education System.

Confederation of Turkish Trade Unions (TISK) (2012, April). January 2012 Evaluation of TUIK HIA data. TISK Labor Market Bulletin, (18). Retrieved August 21, 2012 from http://www.tisk.org. tr/duyurular

Confederation of Turkish Trade Unions, TISKK Labor Market Bulletin (2011), (17). Evaluation of Annual TÜIK Data. Retrieved March 15, 2012 from http://www.thisk.org.tr/.

Guindon, M. H., \& Richmond, L. J. (2005). Practice and research in career counseling and development2004. The Career Development Quarterly, 54, 90-137.

Güngör, E. (1986). Change of culture and Nationalism. İstanbul, Ötüken Publications.

Gür, T. H. (2008). Labor market and working opportunities, In. Career Journey (Ed. Ragip Özyürek). European Union Lifelong learning Program. European Guidance Center Euroguidance, (141161).

Gysbers, N. C., \& Heppner, M. J. (2002). Career Counseling: Process, Issues, and Techniques. American Counseling Association.

Herring, R. D. (1998). Career counseling in schools: Multicultural and developmental perspectives. American Counseling Association. USA.

Herr, E. L. ve Cramer, S. H. (1996). Career guidance and counseling through the life span: Systematic approaches (5th. Ed.). New York: Harper Collins.

Hofstede, G. (2001). Culture's consequences: Comparing values, behaviours, institutions and organizations across nations (2nd. Ed.). Thousand. Oaks, CA: Sage.

Imamoğlu, E. O., Kuller R. V., Imamoğlu, M., \& Kuller, M. (1993). Social psychological world of Swedes and Turkish around retirement. Journal of Cross-Cultural Psychology, 24, 26-41.

İşçi, M. (2000). Social Impacts of Industrialization on Turkish Family. Master's Thesis, Isparta.

Karagöl, T. K. \& Akgeyik, T. (2010). The State of Employment in Turkey: General Tendencies. Seta Analysis. Seta, Politics, Economy and Societal Research Foundation. May, 2010.

Karal, E. Z. (1954). Ottoman History, VI. Volume Period of Royal Edict of Reform 1856-1861. Turkish Historical Society Publishing, Ankara.

Kılıçbay, M. A. (2000). State of East Republic of West, Ankara: İmge Publications.

Kıvilcımlı, H. (1996). Effects of Religion on Turkish Society. İstanbul, Diyalektik Publications.

Kongar, E. (1995). Societal Change, Theories and Turkish Reality, Remzi Publication, İstanbul.

Korkut, F. (2005). Situation of career counseling in Turkey. Proceedings of the First International Conference Career Counseling and the Global Labor Market. May $31^{\text {st }-J u n e ~} 2^{\text {nd }}$. Petru Maior University, Targu Mures, Romania.

Kurtcephe, İ., \& Balcıŏlu, M. K. (1991). History of Military Academy. Military Academy Publishing. Ankara.

Kuzgun, Y. (1998). Higher Education Programs at Universities and Guidebook of Professions. Fourth edition. Ankara: ÖSYM Publication.

Kuzgun, Y. (2000). Vocational Guidance: Theories, Practices. Nobel Publication. Ankara.

Mocan-Aydın, G. (2000). Western models of counseling and psychotherapy within Turkey: crossing cultural boundaries. Counseling Psychologist, 28, 281-298.

McWhirter, J. J. (1983). Cultural factors in guidance and counseling in Turkey: The experience of a Fulbright family. The Personnel and Guidance Journal, 61 (8), 504-507.

Organization for Economic Co-operation and Development (2004). Career guidance and public policy: Bridging the gap. Paris: OECD. 
PROBLEMS

OF EDUCATION

IN THE $21^{\text {st }}$ CENTURY

Volume 48,2012

146

Özgüven, E. (1990). The Past and Current Psychological Counseling and Guidance Services in Turkey. Journal of the Psychological Counseling and Guidance, 1 (1), 4-7.

Özkalp, E. (1993). Introduction to Sociology, Anadolu University, Education, Health and Scientific Research Foundation Publishing, (87), Eskişehir.

Sabah Gazetesi, (2012). Işsizlik rakamı açıklandı. Retrieved August 21, 2012, from http://www.sabah. com.tr/Ekonomi/.

Savickas, M. L. (2000). Assessing career decision making. In E. Watkins \& V. Campbell (Eds.), Testing and assessment in counseling practice (2nd., pp. 429-477). Hillsdale, NJ: Lawrence Erlbaum.

Stockton, R., \& Yerin-Güneri, O. (2011). Counseling in Turkey: Evolving Field. Journal of Counseling and Development, 89, 98-104.

Sultana, R. G. (2003). Review of career guidance policies in 11 acceding and candidate countries. A synthesis report. Turin: European Training Foundation.

Sultana, R.G. (2004). Guidance policies in the knowledge society: Trends, challenges and responses across Europe. Cedefop Panorama series; 85. Luxembourg: Office for Official Publications of the European Communities,

Sultana, R. G., \& Watts, A. G. (2008). Career guidance in the Middle East and North Africa. Introduction to Journal for Educational and Vocational Guidance, 8, 19-34.

Sultana, R. G. (2009). Career Guidance Policies: Global Dynamics, Local Resonances. University of Derby. International Center for Guidance Studies.

Sultana, R. G. (2011). Learning career management skills in Europe: a critical review. Journal of Education and Work, 25 (2), 1-24.

Sümer, S. (1998). Incongruent modernities: A comparative study of higher educated women from urban Turkey and Norway. Acta Sociologica, 41,115-129.

Turkish Republic Ministry of National Education, Seventh National Education Conference Documents (5-15 February 1962), 89-92.

Turkish Republic. Higher Education Council (2011). Higher Education Bologna Process: Quality Assurance. Retrieved September 11, 2012 from http://bologna.yok.gov.tr.

Turkish Republic, Ministry of National Education, (2012). Compulsory Education, Questions-Answers, Retrieved September 27, 2012 from http://www.meb.gov.tr/duyurular

Turkish Republic Ministry of National Education. National Education 2011-2012 Statistics: Formal Education. Retrieved September 27, 2012 from http://sgb.meb.gov.tr/istatistik/meb_ istatistikleri

T. C. Türkiye İstatistik Kurumu Başkanlığı (TUIK). (2012). Haber Bülteni, Hanehalkı İşgücü İstatistikleri, Haziran, 2012. Retrieved September 27, 2012 http://www.tuik.gov.tr/

Ültanır, E. (2005). Psychological Counseling and Guidance Profession in Turkey and Psychological Counselor Education. Mersin University, Education Faculty Journal, 1 (1), 102-112.

Ültanır, Y. G. \& Ültanır, E. (2010). Exploring the curriculum dimensions of theories-based Adult Education-A sample course of the Southeast Anatolian region. International Journal of Instruction, $3(2), 3-24$.

Ultanir, G., \& Ultanir, E. (2012). New Structures in Public Education Centers in Turkey. Problems of Education in the 21st. Century, 44, 92-100.

Ültanır, Y. G. (2012). Thinkers Creating Schools and Continuation of their Impacts. Comparative Education Reflections. Ed: Songül Aynal. Pegem Akademi. Ankara.

Yeşilyaprak, B. (2011). Mesleki Rehberlik ve Kariyer Danışmanlığında Paradigma Değişimi ve Türkiye Açısından Sonuçlar: Geçmişten Geleceğe Yönelik Bir Değerlendirme. Kuram ve Uygulamada Eğitim Bilimleri $\bullet$ Educational Sciences: Theory \& Practice, 11 (4), 5-26.

Watts, A. G., \& Fretwell, D. (2004). Public policies for career development: Policy strategies for designing career information and guidance systems in middle-income and transition economies. Washington, DC: World Bank.

Institute of Social Sciences, Human Resources Management and Career Counseling Department: Master program. Retrieved from http://sosbilens.ankara.edu.tr/UserFiles/File/ogrenci_rehberi_ insankaynak.pdf.

University Bahcesehir Career Counseling Master Program (2012). Retrieved September 27, 2012 from http://www.coop.bahcesehir.edu.tr/sayfa/kariyer_danismanligi. 
Emel ÜLTANIR. The Factors Affecting Career Guidance and Current Status of Career Guidance Services in Turkey

\begin{tabular}{l|l} 
Advised by Laima Railiene, University of Siauliai, Lithuania & $\begin{array}{l}\text { PROBLEMS } \\
\text { OF EDUCATION } \\
\text { IN THE 21 } 1^{\text {st }} \text { CENTURY } \\
\text { Volume 48, 2012 } \\
147\end{array}$
\end{tabular}

Received: September 11, 2012

Accepted: November 10, 2012

Emel Ultanir

PhD., Professor, Department of Educational Sciences, Educational Faculty, Hasan Kalyoncu University in Gaziantep, Turkey.

Phone: 90 (0342) 2118080.

E-mail: emultanir@yahoo.de

Website: http://www.gazikent.edu.tr/ 